\title{
Role of Zarqa University in Improving the Quality of the Services Provided to the Local Community in Zarqa Governorate
}

\author{
Majed Abdel-Mohdi Masadeh ${ }^{1}$ \\ ${ }^{1}$ Department of Business Administration, Faculty of Economics and Administrative Sciences, Zarqa University, \\ Jordan \\ Correspondence: Majed Abdel-Mohdi Masadeh, Associate Professor at Department of Business Administration, \\ Faculty of Economics and Administrative Sciences, Zarqa University, Jordan. Tel: 962-796-052-530. E-mail: \\ masadeh.majed@yahoo.com
}

Received: Oct. 16, 2018 Accepted: Nov. 1, $2018 \quad$ Online Published: December 31, 2018

doi:10.5539/mas.v13n1p192

URL: https://doi.org/10.5539/mas.v13n1p192

\begin{abstract}
The study aimed to identify the role of Zarqa university in improving the quality of the services provided to the local community in Zarqa governorate. The study also sought to identify the degree of the university's interest in the quality of its services provided to the local community from the perspective of its employees, and have been using the scientific method, which combines the descriptive method and analytical method, so the researcher designed a questionnaire for this purpose, based on some previous studies related to the study, and the questionnaire included in its final form on (45) paragraph, and was test the sincerity of the instrument and its stability, and the stability coefficient of the total instrument is $(0.867)$. The study was conducted on the members of the faculty and administrative staff at the Zarqa University (580), due to the study population size is large, the researcher resorted to select a stratified random sample with percentage $(25 \%)$ of the total study population, where the final sample is (98) member of faculty and administrative. The study found a number of results was the most important: that there were no statistically significant differences at the of significance level $(\leq \alpha 0.05)$, between the responses of the employees of Zarqa University about the role of Zarqa university in improving the quality of the services provided to the local community in Zarqa governorate attributed to some personal and functional characteristics represented by (gender, specialty of faculty, Scientific qualification, and experience years).
\end{abstract}

Keywords: quality of services, local community, Zarqa University, Zarqa governorate, Jordan

\section{Introduction}

The competition in the global market between companies has moved to institutions of higher education, but it is another type: it is based on innovation and development in order to achieve the highest returns, accompanied by central transformations to adapt at the so-called information society and global knowledge, and rapid developments in communication and information systems, even higher education has become the focus of attention of governments, institutions and individuals; for their awareness of its active role in shaping the future paths of the countries and communities (Al-Taai, et al., 2008).

In the third millennium, the success of universities in the competition process coupled with the quality in education, in the sense of the ability to turn learns to services or products eligible for competition, by meeting the universities to the needs of their communities; and becomes the workplace and production arena for the use of education and the application of knowledge, is reflected on the creative university capabilities, and their growth and development (Olaimat, 2004).

While the level of university performance does not rise, without going to the modern administrative concepts and taking them, such as: the concept of total quality management (TQM), which is one of the most modern management methods successful; so as to link the size and quality of university services with the administrative system which taken from the mission of the university starting point in applying the guidance principles and University Ethics (Daradke, 2004).

Total Quality Management (TQM) featured, as a result of link the success of the management of productive efficiency, which achieve to increase the productivity and continued the quality, until it became integrated strategy 
for the development of the productive and service institutions, including educational institutions; it focuses on the work correctly and style typical, prevent the exploitation of resources or nuking, and reduces the conflicts level, supports the innovation, and satisfies the beneficiaries (Hernande, 2001).

Due to the education is a commodity like other commodities; came attention to quality control in educational institutions; it must have to compete and seek to satisfy consumers of students, society and the state, so the students are willing to acquire better qualifications for career opportunities less than the increase in number of graduates, limited employment opportunities available, as parents are keen to provide proper education for their sons, and the state is seeking to distinct learning outcomes to enable them to achieve the goals of development plans (Barakat, 2003).

The concept of TQM in tertiary education is focused on directing all academic, administrative and financial activities and processes at all levels in the higher education system to satisfy the needs of the labor market and students by developing and continuously improving the quality of service provided to students in order to obtain an efficient graduate which is needed by the labor market, by creating a new organizational culture based on commitment to customer orientation (students and labor market), the management's commitment to continuous improvement and the principle of collective participation, and the evaluation of the adequacy of the academic, administrative and financial situations to agreement with the entrance of the Total Quality Management (Shiraz, 2003).

The total quality entrance includes several administrative ideas, and consistent with the objective values to a large extent, in order to satisfy the students, community, and the development of openness and trust, teamwork, continuous progressive improvement, and attention to incentives to increase productivity, and the application of quality management in universities requires faith and support of senior management, and change the logic of the prevailing organizational relationships, and remove the creativity obstacles, to create the administrative organization of the activity of quality in the university and ensure its sustainability, and taking into account the privacy of students in the application of the principle of external customer satisfaction in addition to taking into account that the beneficiary community institutions of graduates as an external client for universities (Jouda, 2012).

The University's function extends beyond the education process and the scientific research to the service of the community, which includes aspects beyond that, and the services provided by the university to the community: the placement of faculty members as consultants and experts in various work and production sites, and training of workers in different sectors of community to increase their capacity and productivity, and to link the university admissions with the community needs in order to provide them with both quantitative and qualitative scientific and technical skills (Harian, 2001).

The University has trained staff and qualified technically and scientifically, they are best able to provide its services and expertise in several areas such as continuing education through various programs and courses for the community and nominal fees, and the provision of appropriate scientific and technical advice to different institutions of society, and to provide other services, such as software development, as well as the use of the university resources and services for simple wages (Aly, 2001).

The community service is the first goal of the activity of the free university service; it provides expertise and various services in the fields of medicine, agricultural, engineering, social, sports, the surrounding areas, by forming a working group comprising members of the faculty and students of the University, it offers a variety of services contribute to develop the skills and attitudes of the students behavioral directly related to the basics of the different specialties, in addition to increasing the experience of faculty members by informing them closely on the problems of community, and then employ them in their lectures and the theoretical and practical researches (Sekaran, 2003).

Since the university is a social institution affected by the social environment and affect it, it was incumbent on each university to have a role to play in the service of community; it is a creation of intellectual leadership, professional, artistic, has become a university education in the atheist and the twentieth century is based on the continuing university with community, through the provision of various services to a wider segment of community; in order to bring about positive changes, leading to the progress of community and its development (Al-Rashid, 2005).

The universities are among the most developed and influential institutions in the life of communities, institutions, and constitute the most important tributaries of the development, which means to meet the requirements of different needs and developed in other areas, and to stand on the problems faced by finding appropriate solutions to them, and to detect talent and capabilities of individuals, and to work on investment and highlighted (Al-Fatlawi, 2006). 
The community service provides universities with economic benefits. It is an additional source of funding that supports the budgets of universities and enables them to secure scientific research materials from laboratories, equipment, materials and scientific resources. The community service is also an additional source of material and financial support to faculty members in the universities, when you're doing researches and applied studies which required by the community institutions (Al-Harahsheh, 2009).

\subsection{The Study Problem and its Questions}

Has become the quality of education of the important issues of care increased recently by the concerned higher education in different countries, due to the awareness of importance of the role of education in sustainable human development, and the growing pressure and criticism faced by this sector, it is still below the level of ambition and efforts which are being made to support the overall activities of the State, which led to the emergence of a strong trend trying hard to improve the efficiency of the educational system, by improving the overall quality of its outputs, and the commitment of universities and social responsibility towards the community in which it operates, through the extensive contribution of social activities, and based on the above it can be summarized the study problem in the following two questions:

1. What is the employees' assessment for the role of Zarqa university in improving the quality of the services provided to the local community in Zarqa governorate?

2. Is there a difference between the employee's responses at Zarqa University about the role of Zarqa university in improving the quality of the services provided to the local community in Zarqa governorate according to some personal and functional characteristics represented by (gender, specialty of faculty, scientific qualification, and experience years)?

\subsection{The Study Importance}

The study importance highlights from the vitality of the subject, which is the quality of services provided to the community, which is a means to the industry of the renaissance of the community, and a tool for development in it, so the quality assurance in the service of the local community has become a means to ensure the achievement of the educational system for its objectives, also the study importance highlights from the importance of the role played by the application of total quality standards in the educational institutions and their development, and in enabling them to prepare qualified cadres able to meet the needs of the community and its development.

\subsection{The Study Objectives}

This study seeks to achieve a number of objectives are as follows:

1. To recognize the reality of the services offered by Zarqa University to the local community.

2. Disclosure of the quality level of services at Zarqa University.

3. To recognize the role of Zarqa university in improving the quality of the services provided to the local community in Zarqa governorate.

4. Measuring the differences between the employee's responses at Zarqa University about the role of Zarqa university in improving the quality of the services provided to the local community in Zarqa governorate according to some personal and functional characteristics represented by (gender, specialty of faculty, scientific qualification, and experience years).

\subsection{The Study Hypotheses}

\section{The main hypothesis:}

$\mathbf{H}_{0}$ : There is no statistically significant differences at the significance level $\quad(\alpha \leq 0.05)$, between the employees' responses about the role of Zarqa university in improving the quality of the services provided to the local community in Zarqa governorate attributed to some personal and functional characteristics represented by (gender, specialty of faculty, scientific qualification, and experience years).

It stems from the main hypothesis, the following four sub-hypotheses:

$\mathbf{H}_{01}$ : There is no statistically significant differences at the significance level $\quad(\alpha \leq 0.05)$, between the employees' responses about the role of Zarqa university in improving the quality of the services provided to the local community in Zarqa governorate attributed to the (gender) variable.

$\mathbf{H}_{02}$ : There is no statistically significant differences at the significance level $\quad(\alpha \leq 0.05)$, between the employees' responses about the role of Zarqa university in improving the quality of the services provided to the local community in Zarqa governorate attributed to the (specialty of faculty) variable. 
Ho3: There is no statistically significant differences at the significance level

$(\alpha \leq 0.05)$, between the employees' responses about the role of Zarqa university in improving the quality of the services provided to the local community in Zarqa governorate attributed to the (scientific qualification) variable.

$\mathbf{H}_{04}$ : There is no statistically significant differences at the significance level $(\alpha \leq 0.05)$, between the employees' responses about the role of Zarqa university in improving the quality of the services provided to the local community in Zarqa governorate attributed to the (experience years) variable.

\subsection{Sources of Data Collection}

The study relied on two main sources of data collection which are:

1. Preliminary data: The data were collected by a questionnaire that was prepared and distributed to respondents, and included (45) paragraphs to measure the attitudes of faculty members towards the role of the university in serving the local community.

2. Secondary data: The collection of this type of data by reference to the theoretical studies, books, references, articles, scientific research published in the journals and periodicals.

\subsection{The Previous Studies}

- Study of (Al-Tal \& Al-Sarairah, 2013): The study aims to identifying the interest degree of Mu'tah University in the quality of its role in the service of the local community in the light of the estimates of the faculty members in the university and to identify on the impact of the variables of the taxonomic study in these estimates. And it adopted a questionnaire from (36) paragraphs according to three areas and then applied to a sample of (221) faculty members. The study found there are statistically significant differences between the averages of these estimates attributed to the impact of the overall status in the field of "the reputation of the university" in favor of the scientific colleges, and for the impact of academic rank in the field of "interaction with the community, and the reputation of the university" and all fields in favor of the rank of professor, while the study found there is no statistically significant differences between the averages of estimates attributed to the impact of the overall status in the areas of "the university's policy towards the relationship to society, and interaction with the community" and all fields, and for the impact of academic rank in the field of "the university's policy towards the relationship of society in", and for the impact of experience in university teaching in each field and all fields.

- Study of (Al-Khaddam, 2013): The study aimed to detect the university youth attitudes towards practice of the volunteer work, the researcher has used two entrances of the descriptive approach entrances: the entrance to the documentary studies to illustrate the theoretical background of volunteer work, and the second entrance to the social survey sample in order to survey of the university youth attitudes towards volunteering. The researcher designed a questionnaire for this purpose, based on some previous studies related to, the questionnaire in its final form on (25) paragraph, and the validity of the tool were tested and its stability. The study was conducted on a sample of students from Ajloun University College of (300) students, and the study results showed that the attitudes of the study sample towards voluntary work were (positive), also the results showed that there were no statistically significant differences between students Ajloun University College attitudes towards voluntary work attributed to the variables of specialization, academic level, and age.

- Study of (Al-Rawashdeh, 2011): The study aimed to identify the role of Al-Balqa Applied University to the community service. The scientific method that combines between the descriptive and analytical methods was used, and adopted a questionnaire that included a sample of all faculty members in Ajloun University College at AlBalqa Applied University. The study results showed that the role of the university in the community service was the middle importance, also the results shown that there were statistically significant differences in their opinions about the university's role in the community service attributed to the variable gender in favor of (females), the experience years in favor of (10 years and more), and for the academic rank in favor of (Assistant Professor).

- Study of (Ibn Sultan, 2009): The study aimed to detect the attitudes of university youth to practice of the volunteering and what voluntary work they wish to practice, as well as identifying the obstacles that prevent them from joining volunteer work. In order to achieve these objectives, a questionnaire was implemented and consists in the final form of (65) paragraphs divided into six areas and then applied on a sample of (28) thousand students. The study results showed that the average practice of university youth to volunteer work is very weak, and that the university young male attitudes positive towards of the voluntary work, for example, preserving the environment and combating drugs and smoking, and came in the forefront of areas in which university youth want to participate in it. The study results showed that the acquisition of new skills, and increasing experience, leisure useful things time and help in the community service, self-confidence, and the development of social personality comes at the forefront of the benefits to young people because of their participation in the voluntary work, and they see it very 
high importance.

- Study of (Farrari \& Bristow, 2008): The study aimed to identify the views of university students towards the university environment and its relationship with incentives to serve the local community and engage in public service. This study was conducted on the students of the American De Paul University in the state of Illinois. The study sample consisted of (120) respondents. The study found that the students in the first and second years have a high impression that the university provides a suitable environment for students to carry out the volunteer work in the community and that they have higher incentives than the third and fourth year students to carry out the volunteer work, especially incentives related to the public interests, and to respond to the needs and the desire to provide assistance to others. The study results showed that there are significant differences between the students views about the university environment and its relationship with incentives to serve the local community, and that the reason for these differences is due to the first and second years students had been too much for mentoring programs and projects of community service, especially the first year students, but those incentives were less at the students of the second, third and fourth years and for several reasons, most notably: many of them busy working to cover the cost of university study, and lack of exposure to public service programs.

- Study of (Al-Rasheed, 2005): The study aimed to explain the role of Jordanian universities in service of the community. The study adopted a questionnaire and included a sample of all the faculty members and the staff in Jordanian universities. The study results showed that the faculty members and the staff at the Jordanian universities appreciate the role of universities in a medium degree of the community service, and showed that there were no statistically significant differences between the average of their estimations of the universities degree in their role in service of the community attributed to the job title, and type of university.

- Study of (Jones \& Hill, 2003): The study aimed to detect at the incentives for students to the volunteer service and the study sample was purposed consisting of (24) students from four higher education institutions in the state of Ohio. And all respondents have done the volunteer work during their studies at the secondary school level. And the half of them continued to do the volunteer work after moving to the university, while the other half stopped him after moving from the university. The study found that the participation of students in the volunteering during high school was due to the influence of the external incentives such as encouraging family and friends, because work is required in the curriculum, encouraging religious beliefs, helping others, and doing the volunteer work helps students to obtain university admission. While the students who stopped after moving to the university said that the main reasons for this interruption were: lack of time, concern about prioritizing their new life at the university, preoccupation with university work and moving to a new community (university and surrounding areas).

- Study of (Bringle \& Hatcher, 2002): The study aimed to identify the partnership between the university and the local community. The study found that the higher education institutions in the United States contributed to providing the services and activities to the local communities in several ways, notably: continuing education programs, clinical and professional programs, finding academic departments or units or administrative, professional services for teachers, in the local community, and the local community's benefit from the university and its cultural activities. Also, the study showed that the voluntary contribution of the students, teachers and administrators helps to improve the service of the local community, and its development in many areas, which ultimately leads to build the trust between the higher education institutions and the local community.

- Study of (Tiamiya \& Bailey, 2001): The study aimed to identify by the community services for colleges and the role of the communication between the university and the community in which, revealed the results of the study in response (24) agency for services according to the survey, which was about the services provided for adults, showed that the employees in these agencies did not have negative perceptions about the cooperation between the university and the community in order to provide these services, but they did not realize how cooperation between them, So this cooperation has been able to improve the services in light of increasing the demand due to growing trends and increasing the population. And the conclusion which understood from this study: that the university can provide the services in light of increasing the population of community and improving their conditions.

- Study of (Schumaker \& Wood, 2001): The study aimed at defining the role of the university college in community service in light of the experience of Nebraska College. A highlight of the study results provide views can be utilized in light of experience, which extends to thirty years for its College of the University of Nebraska to provide community services in public affairs and community development, and showed that this distinguished faculty supported the research and the participants in the community, and thus succeeded with the help of the university to form part of the community. The conclusion of this study that the faculty role in activating the university and help them to be part of the community, and the commitment to its role in the service and development. 


\section{Method}

\subsection{The Study Approach}

The study used the descriptive and analytical approach to accomplish this study, and was used the descriptive method to describe the role of Zarqa University of local community service from the perspective of faculty members and administrators in, also been used as the analytical method to measure the differences between the employees' responses about the role of Zarqa university in improving the quality of the services provided to the local community in Zarqa governorate according to some of the personal and functional characteristics of (gender, specialty of faculty, academic qualification, experience years).

\subsection{The Study Population and its Sample}

The study population consists of all faculty members and administrator whom are working at Zarqa University of (580) faculty member and administrator. And the study sample consists of (145) faculty member and administrator, selected according to stratified random sample method, with (25\%) from the population. After that the researcher distributed (145) questionnaire on the study sample, were returned (112) questionnaire, where the percentage of questionnaires returned is $(87.5 \%)$, and after review and audit questionnaires returned, were excluded (14) questionnaires for not expire because of lack of the information contained in each, and thus the number of valid questionnaires for the statistical analysis (98) questionnaire. As shown in the following Table (1).

Table 1. The study population and its sample, distributed questionnaires number, and valid questionnaires

\begin{tabular}{ccccccc}
\hline The Profession & $\begin{array}{c}\text { Population } \\
\text { Size }\end{array}$ & $\begin{array}{c}\text { Sample } \\
\text { Size }\end{array}$ & $\begin{array}{c}\text { Distributed } \\
\text { Questionnaires }\end{array}$ & $\begin{array}{c}\text { Retrieved } \\
\text { Number }\end{array}$ & $\begin{array}{c}\text { Valid } \\
\text { Number }\end{array}$ & $\begin{array}{c}\text { Valid } \\
\text { Ratio }\end{array}$ \\
\hline Teaching staff & 300 & 75 & 75 & 60 & 56 & $\% 93.3$ \\
Administrator & 280 & 70 & 70 & 52 & 42 & $\% 80.8$ \\
Total & 580 & 145 & 145 & 112 & 98 & $\% 87.5$ \\
\hline
\end{tabular}

\subsection{The Study Tool}

The researcher reference to the relevant studies and researches and a number of tools and references that interested in role of the universities in the local community, view to designing a questionnaire of study for the purposes of collecting information and data, the tool consisted of (45) items distributed on three axes represented by (the university's reputation, the university's policy toward the community, and interaction with the community). After completion of design the study tool was measured the tool sincerity and its reliability, as follows:

\subsubsection{Tool Sincerity}

Has been verified the Face Validity of the study tool (questionnaire), and through the presentation on five arbitrators with expertise and knowledge from teaching faculty members at Jordanian universities, in the terms of reference of administrative sciences, and was the aim of the arbitration verify the extent of items belonging to the study variables, an appropriate degree of drafting items Linguistically, where been modification reworded drafting some of items.

\subsubsection{Tool Reliability}

Having been assured of the study tool validity and the readiness of its application, on the study sample of (98) faculty member, and for the purpose of verifying of the internal consistency of the questionnaire items of the study variables, the researcher used for this purpose (Cronbach's alpha) coefficient to measure the (internal consistency of the questionnaire items), which equals to the total tool (0.867), and this value is very good for the administrative and humanitarian researches. As shown in the following Table (2):

Table 2. Results of reliability (Internal Consistency of the items)

\begin{tabular}{llll}
\hline No. & The Variables & No. of Items & Cronbach's Alpha \\
\hline 1 & The university's reputation & 15 & 0.842 \\
2 & The university's policy toward the community & 15 & 0.861 \\
3 & Interaction with the community & 15 & 0.876 \\
- & Overall Tool & 45 & 0.867 \\
\hline
\end{tabular}


In light of the foregoing, the data that were obtained through the application of the study tool, considered valid for the purposes of the statistical analysis and calculation of the statistical indicators for the purpose of answering about the study questions and test its hypotheses.

\section{Results}

This section devoted to present the results of the statistical analysis of the data subjects' responses of the study sample, which was reached through the use of the Statistical Package for Social Sciences (SPSS), in order to answer the study question and test the hypotheses.

\subsection{Results of the Study Question}

What is the employees' assessment for the role of Zarqa university in improving the quality of the services provided to the local community in Zarqa governorate?

For the purpose of answering on the study question, were account the means, standard deviations, and loadings in order to stand on the estimates of employees about of their evaluation level for quality of the services provided to the local community which are (the university's reputation, university's policy toward the community, and interaction with the community). As shown in the Table (3) below:

Table 3. Results of Means, Standard Deviations, and Loadings for Variables

\begin{tabular}{llllll}
\hline No. & Quality of services & Mean & Std. Dev. & Loadings $\left(^{*}\right)$ & Rank \\
\hline 1 & The university's reputation & 4.09 & 0.63 & 0.929 & 1 \\
2 & $\begin{array}{l}\text { The university's policy toward the } \\
\text { community }\end{array}$ & 3.98 & 0.73 & 0.911 & 2 \\
3 & Interaction with the community & 3.74 & 0.46 & 0.752 & 3 \\
\hline
\end{tabular}

$(*)$ The Loadings values calculating by using Factor Analysis.

Evident from the results in Table (3), that (The university's reputation) axis get on the (first) rank in terms of its importance for the study sample, with mean was (4.09) and loading of (0.929), and (The university's policy toward the community) axis get on the (second) rank, with mean was (3.98) and loading of (0.911), and finally (The interaction with the community) axis came in (third) rank and the last on the ladder of priorities for the employees in Zarqa University estimates, with mean was (3.74) and loading of (0.752).

\subsection{Results of testing the Hypotheses}

$\mathrm{H}_{0}$ : There is no statistically significant differences at the significance level $(\alpha \leq 0.05)$, between the employees' responses about the role of Zarqa university in improving the quality of the services provided to the local community in Zarqa governorate attributed to some personal and functional characteristics of (gender, specialty of faculty, qualification, and experience years).

To test validity of the study hypothesis of not validity, was used the Independent Samples (t-Test), and One-way analysis of variance (ANOVA). And to achieve this, it should make sure validity of the sub-hypotheses emanating from it or not, as follows:

\subsubsection{Results of testing the $1^{\text {st }}$ Sub-hypothesis}

$\mathrm{H}_{01}$ : There is no statistically significant differences at the significance level $(\alpha \leq 0.05)$, between the employees' responses about the role of Zarqa university in improving the quality of the services provided to the local community in Zarqa governorate attributed to (gender).

In order to test validity of the $1^{\text {st }}$ sub-hypothesis of not validity, was used the Independent Samples (t-Test). It is evident from the means values contained in the Table (4), their existence morphological differences between the means of the employees responses about the role of Zarqa university in improving the quality of the services provided to the local community in Zarqa governorate, attributed to (gender). To detection of the significance of differences between the means of the employees' estimates about the role of Zarqa university in improving the quality of the services provided to the local community in Zarqa governorate, attributed to (gender), was used (ttest) for two independent samples.

Table 4. Results of (t-Test), to measure the differences between the employees' responses about the role of Zarqa 
University in improving the quality of the services provided to the local community in Zarqa governorate attributed to (gender)

\begin{tabular}{lllllc}
\hline Variables & Gender & Mean & Std. Dev. & t-value & Sig. \\
\hline The university's reputation & Male & 4.01 & 0.76 & & \\
& Female & 4.20 & 0.33 & -1.465 & 0.146 \\
The university's policy & Male & 3.85 & 0.89 & & \\
toward the community & Female & 4.18 & 0.32 & -1.266 & 0.226 \\
Interaction with the & Male & 3.71 & 0.47 & & \\
community & Female & 3.79 & 0.46 & -0.818 & 0.416 \\
\hline
\end{tabular}

Evident from the results listed in Table (4), that there were no statistically significant differences at the significance level $(\alpha=0.05)$, between the employees' responses about the role of Zarqa university in improving the quality of the services provided to the local community in Zarqa governorate which are (the university's reputation, the university's policy toward the community, and the interaction with the community), attributed to (gender), which is supported by the calculated values of (t-test) for the mentioned axes, and that the statistical significance values (Sig.) for these axes is greater than the significance level $(\alpha=0.05)$. This means that the employees' responses about the role of Zarqa University in improving the quality of the services provided to the local community in Zarqa governorate to be equivalents to have regardless of their sex. This means that will be not rejecting the null sub-hypothesis $\left(\mathrm{H}_{01}\right)$.

\subsubsection{Results of testing the 2nd Sub-hypothesis}

$\mathrm{H}_{02}$ : There is no statistically significant differences at the significance level $(\alpha \leq 0.05)$, between the employees' responses about the role of Zarqa university in improving the quality of the services provided to the local community in Zarqa governorate attributabed to (specialty the college) variable.

In order to test validity of the $2^{\text {nd }}$ sub-hypothesis of not validity, was used the Independent Samples (t-Test). It is evident from the means values contained in the Table (5), their existence morphological differences between the means of the employees' responses about the role of Zarqa university in improving the quality of the services provided to the local community in Zarqa governorate according to (specialty the college). To detection of the significance of differences between the means of the employees' estimates about quality the role of Zarqa university in improving the quality of the services provided to the local community in Zarqa governorate, attributed to (specialty the college), was used (t-test) for two independent samples.

Table 5. Results of (t-Test), to measure the differences between the employees' responses about the role of Zarqa university in improving the quality of the services provided to the local community in Zarqa governorate attributed to (specialty the college)

\begin{tabular}{|c|c|c|c|c|c|}
\hline Variables & $\begin{array}{l}\text { Specialty } \\
\text { College }\end{array}$ & Mean & Std. Dev. & t-value & Sig. \\
\hline \multirow[t]{2}{*}{ The university's reputation } & Scientific & 4.15 & 0.49 & & \\
\hline & Humanity & 4.02 & 0.76 & 0.982 & 0.329 \\
\hline \multirow{2}{*}{$\begin{array}{l}\text { The university's policy } \\
\text { toward the community }\end{array}$} & Scientific & 3.99 & 0.71 & & \\
\hline & Humanity & 3.97 & 0.77 & 0.139 & 0.890 \\
\hline \multirow{2}{*}{$\begin{array}{l}\text { Interaction with the } \\
\text { community }\end{array}$} & Scientific & 3.78 & 0.45 & & \\
\hline & Humanity & 3.70 & 0.48 & 0.861 & 0.392 \\
\hline
\end{tabular}

Evident from the results listed in Table (5), that there were no statistically significant differences at the significance level $(\alpha=0.05)$, between the employees' responses about the role of Zarqa university in improving the quality of the services provided to the local community in Zarqa governorate which are (the university's reputation, the university's policy toward the community, and the interaction with the community), attributed to (specialty the college), which is supported by the calculated values of (t-test) for the mentioned axes, and that the statistical significance values (Sig.) for these axes is greater than the significance level $(\alpha=0.05)$. This means that the employees' responses about the role of Zarqa university in improving the quality of the services provided to the local community in Zarqa governorate to be equivalents to have regardless of their specialty the college. This means that will be not rejecting the null sub-hypothesis $\left(\mathrm{H}_{02}\right)$.

\subsubsection{Results of testing the $3^{\text {rd }}$ Sub-hypothesis}


$\mathrm{H}_{03}$ : There is no statistically significant differences at the significance level

$(\alpha \leq 0.05)$, between the employees' responses about the role of Zarqa university in improving the quality of the services provided to the local community in Zarqa governorate attributed to (qualification).

In order to test validity of the $3^{\text {rd }}$ sub-hypothesis of not validity was used One-way analysis of variance (ANOVA). It is evident from the means values contained in the Table (6), their existence morphological differences between the means of the employees' responses about the role of Zarqa university in improving the quality of the services provided to the local community in Zarqa governorate according to (qualification). To detection of the significance of differences between the means of the employees' estimates about the role of Zarqa university in improving the quality of the services provided to the local community in Zarqa governorate, attributed to (qualification), was used One-way (ANOVA).

Table 6. Results of (ANOVA), to measure the differences between the employees' responses about the role of Zarqa university in improving the quality of the services provided to the local community in Zarqa governorate attributed to (qualification)

\begin{tabular}{|c|c|c|c|c|c|}
\hline Variables & Qualification & Mean & Std. Dev. & $F_{\text {ratio }}$ & Sig. \\
\hline \multirow{4}{*}{$\begin{array}{l}\text { The } \\
\text { reputation }\end{array}$} & Diploma & 4.10 & 0.52 & \multirow{4}{*}{0.043} & \multirow{4}{*}{0.958} \\
\hline & Bachelor of & 4.11 & 0.31 & & \\
\hline & Postgraduate & 4.07 & 0.76 & & \\
\hline & Diploma & 4.33 & 0.32 & & \\
\hline \multirow{3}{*}{$\begin{array}{l}\text { The university's policy } \\
\text { toward the community }\end{array}$} & Bachelor of & 4.05 & 0.47 & \multirow[t]{3}{*}{3.048} & \multirow[t]{3}{*}{0.051} \\
\hline & Postgraduate & 3.85 & 0.87 & & \\
\hline & Diploma & 3.69 & 0.48 & & \\
\hline \multirow{2}{*}{$\begin{array}{l}\text { Interaction with the } \\
\text { community }\end{array}$} & Bachelor of & 3.81 & 0.28 & \multirow[t]{2}{*}{0.389} & \multirow[t]{2}{*}{0.679} \\
\hline & Postgraduate & 3.73 & 0.52 & & \\
\hline
\end{tabular}

It is evident from the results contained in the table (6), that there were no statistically significant differences at the significance level $(\alpha=0.05)$, between the employees responses about the role of Zarqa university in improving the quality of the services provided to the local community in Zarqa governorate which are (the university's reputation, the university's policy toward the community, and the interaction with the community), attributed to (qualification), which is supported by the calculated values of (F-ratio) for the mentioned axes, and that the statistical significance values (Sig.) for these axes is greater than the significance level $\quad(\alpha=0.05)$. This means that the employees' responses about the role of Zarqa university in improving the quality of the services provided to the local community in Zarqa governorate to be equivalents to have regardless of their qualifications. This means that will be not rejecting the null sub-hypothesis $\left(\mathrm{H}_{03}\right)$.

\subsubsection{Results of testing the $4^{\text {th }}$ Sub-hypothesis}

$\mathrm{H}_{04}$ : There is no statistically significant differences at the significance level

$(\alpha \leq 0.05)$, between the employees' responses about the role of Zarqa university in improving the quality of the services provided to the local community in Zarqa governorate attributed to (experience years).

In order to test validity of the $4^{\text {th }}$ sub-hypothesis of not validity was used One-way analysis of variance (ANOVA). It is evident from the means values contained in the Table (7), their existence morphological differences between the means of the employees' responses about the role of Zarqa university in improving the quality of the services provided to the local community in Zarqa governorate according to (experience years). To detection of the significance of differences between the means of the employees estimates about the role of Zarqa university in improving the quality of the services provided to the local community in Zarqa governorate, attributed to (experience years), was used One-way (ANOVA).

Table 7. Results of (ANOVA), to measure the differences between the employees' responses about the role of Zarqa university in improving the quality of the services provided to the local community in Zarqa governorate attributed to (experience years)

\begin{tabular}{|c|c|c|c|c|c|c|}
\hline Variables & & Experience Years & Mean & Std. Dev. & $\mathrm{F}_{\text {ratio }}$ & Sig. \\
\hline & & Less than 10 years & 4.06 & 0.83 & & \\
\hline The & university's & $10-15$ & 3.95 & 0.50 & 1.414 & 0.248 \\
\hline
\end{tabular}




\begin{tabular}{llllll}
\hline reputation & 15 year and more & 4.19 & 0.79 & & \\
& Less than 10 years & 4.01 & 0.10 & 7.679 & 0.001 \\
The university's & $10-15$ & 3.61 & 0.77 & & \\
policy toward the & 15 year and more & 4.22 & 0.75 & & \\
community & Less than 10 years & 3.69 & 0.29 & \multirow{2}{*}{0.125} & 0.000 \\
Interaction with the & $10-15$ & 3.47 & 0.30 & & \\
community & 15 year and more & 3.95 & 0.51 & & \\
\end{tabular}

It is evident from the results listed in the Table (7), that:

a. There were no statistically significant differences at the significance level $(\alpha=0.05)$, between the employees' responses about the role of Zarqa university in improving the quality of the services provided to the local community in Zarqa governorate for (the university's reputation), attributed to (experience years), which is supported by the calculated value of (F-ratio) for the mentioned axes, and that the statistical significance value (Sig.) for this axes is greater than the significance level of $(\alpha=0.05)$. This means that the employees' responses the role of Zarqa university in improving the quality of the services provided to the local community in Zarqa governorate to be equivalents to have regardless of their experience years.

b. There exist statistically significant differences at the significance level $(\alpha=0.05)$, between the employees' responses about the role of Zarqa university in improving the quality of the services provided to the local community in Zarqa governorate for (the university's policy towards the community, and interaction with the community), attributed to (experience years), which is supported by the calculated values of (F-ratio) for the mentioned axes, and that the statistical significance values (Sig.) $(0.000,0.001)$ respectively, for these axes is less than the significance level of $(\alpha=0.05)$. This means that the employees' responses about the role of Zarqa university in improving the quality of the services provided to the local community in Zarqa governorate are not disproportionate among them. And these differences was in favor of experience years class (15 years and more) about the mentioned two axes in terms of their means (4.22) and (3.95) respectively, and the two means are greater than the categories means of the other (experience years) for the mentioned two axes. This means that will be reject of the null sub-hypothesis $\left(\mathrm{H}_{04}\right)$.

\section{Conclusions \& Recommendations}

\subsection{Conclusions}

The study concluded a number of conclusions in light of its results, among them the following:

a. The results indicated that (the university's reputation) axis get on the (first) rank in terms of its importance for members of the study sample, and the axis (the university's policy toward the community) came in the (second) rank, and finally the axis (the interaction with the community) came in the (third) rank on the priorities of the employees estimates in Zarqa University.

b. There were no statistically significant differences at the significance level $(\alpha=0.05)$, between the employees' responses about the role of Zarqa university in improving the quality of the services provided to the local community in Zarqa governorate which are (the university's reputation, the university's policy toward the community, and the interaction with the community), attributed to (gender).

c. There were no statistically significant differences at the significance level $(\alpha=0.05)$, between the employees' responses about the role of Zarqa university in improving the quality of the services provided to the local community in Zarqa governorate which are (the university's reputation, the university's policy toward the community, and the interaction with the community), attributed to (specialty the college).

d. There were no statistically significant differences at the significance level $(\alpha=0.05)$, between the employees' responses about the role of Zarqa university in improving the quality of the services provided to the local community in Zarqa governorate which are (the university's reputation, the university's policy toward the community, and the interaction with the community), attributed to (qualification).

e. There were no statistically significant differences at the significance level $(\alpha=0.05)$, between the employees responses about the role of Zarqa university in improving the quality of the services provided to the local community in Zarqa governorate for (the university's reputation), attributed to (experience years) 
f. There exist statistically significant differences at the significance level $(\alpha=0.05)$, between the employees responses about the role of Zarqa university in improving the quality of the services provided to the local community in Zarqa governorate for (the university's policy towards the community, and interaction with the community), attributable to (experience years). And these differences were in favor of experience years class (15 years and more) about the mentioned two axes in terms of their means.

\subsection{Recommendations}

The study reached a number of recommendations in light of its results, among them the following:

a. Necessity focus on of Zarqa University on (the interaction with the community) axis, due to obtaining on the (third) rank and last on the ladder priorities of the employees estimates in the mentioned university.

b. Work on holding workshops for newly recruited employees from teaching and administrative staff in order to emphasize the importance of the quality of its services provided to the local community of the two mentioned (the university's policy toward the community, interact with the community).

c. The study suggests that a similar studies in the future, on the universities or the academy is focused on other axes bodies, taking into account work compared for the study's results that are conducted.

\section{References}

Al-Fatlawi, M. J. (2006). Impact of e Application of the Total Quality Management in the Educational Process: Babylon University Case Study, Master Thesis (Unpublished), Babylon University, Iraq.

Al-Harahsheh, F. (2009). Role of Al-Yarmouk University in the community service from the point of view of the faculty members, Journal of the Human Sciences, Sixth year.

Al-Khaddam, H. K. (2013). Attitudes of university youth towards the volunteering, Ajloun University College as a model, Al-Quds Open University Journal.

Al-Rasheed, M. A. (2005). Role of the University in the community service and the extent of the role of Jordanian Universities in this role, PhD dissertation (Unpublished), Amman, Amman Arab University for Postgraduate Studies.

Al-Rawashdeh, U. Z. (2011). Role of the university in the local community service from the point of view of the faculty members in it, and the relationship with some of their personal variables, Balqa University as a model, Journal of Umm Al-Qura Social Sciences.

Al-Taei, Y., Al-Abbadi, M., \& Al-Abbadi, H. (2008). Total Quality Management in University Education, Amman, Al-Warraq Foundation for Publishing and Distribution.

Al-Tal, W. A. R., \& Al-Sarairah, K. (2013). Degree of interest Mu'tah University in the quality of its role in the community service in light of estimates of the faculty members, University of Mu'tah, Journal of Mu'tah Research and Studies.

Aly, N., \& Akpovi, J. (2001). Total quality management in California Public Higher Education, Quality Assurance in Education.

Badah, A. (2003). A Proposed Model for of Total Quality Management in Jordanian Public Universities, Union of Arab Universities Journal.

Barakat, A. (2003). Impact of application of the total quality systems on the higher education in Jordan: field study, unpublished research.

Bringle, R., \& Hatcher, J. (2002). Campus-Community Partnerships: The Terms of Engagement. Journal of Social Issues, 58(3), 503-516.

Daradkeh, A. (2004). Degree of application of Total Quality Management at Al-Balqa Applied University from the point of view of educational leaders, Master thesis (unpublished), Al-Yarmouk University, Jordan.

Ferrari, J., Bristow, R., \& Maya, J. (2002). Are We Helping Them Serve Others? Student Perceptions of Campus Altruism in Support of Community Service Motives Education, 125(3), 404-413.

Harian, K. (2001). Identifying Baldrige- based school Quality improvement strategies in 1998-1999, Ph.D. Dissertation, Published by Internet, Texas University.

Hernandez, R. (2001). Total Quality Management in Higher Education: The application of TQM in Texas School District, Ph.D. Dissertation, Published by Internet, University of Austin.

Ibn, S. F. (2009). Attitudes of university young male towards the volunteering: applied study at King Saud 
University, Journal of the Arabian Gulf Mission, No. 112, Saudi Arabia.

John, H. (2005). The contribution of volunteering, trust and networks to Educational performance. The Policy Studies Journal, 33(4), 635-656.

Juoda, M. A. (2012). Total Quality Management: concepts and applications, Dar Wael for Publishing and Distribution, Amman, Jordan.

Olaimat, S. N. (2004). Total quality management in educational institutions: the application and development proposals, Dar Al- Shorouk for Publishing and Distribution, Amman, Jordan.

Schumaker, \& wood, (2001). The role of a collage in a university wide approach to community partnership: the university of Nebraska at Omaha experience an international forum, 12(4), 66-79.

Sekaran, M. (2003). Towards the contemporary vision for the universities functions, in light of the future challenges, Dar Al-Huda for Printing, Cairo.

Shiraz, M. I. (2003). Total quality management and possibility of their application in higher education, Master Thesis (unpublished), Faculty of Economics, Tishreen University, Damascus.

Tiamiya M. F., \& Bailey (2001). Human services for the elderly and the role of the university community collaboration. Perceptions of Human Service Agency Workers Educational Gerontology, 2(6), Jul-Aug.

\section{Copyrights}

Copyright for this article is retained by the author(s), with first publication rights granted to the journal.

This is an open-access article distributed under the terms and conditions of the Creative Commons Attribution license (http://creativecommons.org/licenses/by/4.0/). 